\title{
Editorial: Do Stabilisation Policies Stabilise?
}

\section{Christopher Colclough and Reginald Herbold Green}

In one sense the perceived needs to stabilise virtually all African economies, and to secure their structural adjustment to new external realities, are no longer judged controversial both within and outside the African continent. It is now widely accepted that stabilisation -defined as removing untenable macroeconomic imbalances - has become essential. But, at another level, the disagreements have intensified. Critical questions include the following: Does the combination of classic IMF macroeconomic demand management plus liberalisation lead to stabilisation? If so, does it do so at the price of frustrating adjustment and renewed growth? Are conventional ways of adjusting macroeconomic balances remotely good enough if other human imbalances - such as high infant mortality, malnutrition, lack of access to basic health and education services and absolute poverty - become more extended as a result? Or is it that 'stabilisation with an inhuman face' must be judged to be professionally (as well as humanly) irresponsible? Are the post-1980 IMF programmes in Africa classic ones founded in the Polak model or are they something new?

The seven case studies in this volume (Algeria, Ghana, Madagascar, Malawi, Sierra Leone, Togo, Zambia) and the two more general papers (on adjustment with a human face, and non-marginal exchange rate changes) cannot claim to answer these questions definitively. They do, however, pose them sharply; they also throw light on the probable range of answers and cast grave doubt on claims that - in any general sense - 'stabilisation is working'.

Even in its own terms, stabilisation is far from being generally successful. Our studies show that Ghana and Algeria (whose programme was national and in some ways unconventional) have stabilised at a macroeconomic level but that Madagascar, Sierra Leone, Togo and Zambia clearly have not, and that Malawi's stabilisation looks increasingly unlikely.

As regards the restoration of sustainable GDP growth, the pattern is similar - except that the longevity of Ghana's growth remains open to doubt and that of Algeria had barely begun by late 1987, tied as it was to the partial recovery in the price of petroleum. More positively, this does, at least, suggest that successful stabilisation is not inconsistent with structural adjustment and renewed growth. However, causality may run in the opposite direction: it could be that without an early renewal of growth neither structural adjustment nor stabilisation prove to be sustainable.

One area of divergence amongst this group of countries which appears to be important is the behaviour of net resource inflows (grants and loans less interest and repayments). In cases where these did not rise - e.g. Sierra Leone, Togo, Zambia, Madagascar - stabilisation has not been successful in its own terms. Still less has it restored stable growth or halted general deterioration in the human condition. On the other hand, where net resource inflows have increased - as in Ghana and Malawi - initial stabilisation objectives have been met and - less clearly in Malawi's case - growth has been restored. The outcome as regards poverty and destitution, however, even in those countries, remains unclear.

In each of the count ries studied the policy stance prior to the introduction of stabilisation measures was in any case untenable for the longer term. In the absence of reforms, major reductions in public spending, and in demand more generally would have been inevitable. Similarly the distributive impact of pre-stabilisation policies often acted against the interests of the poorest groups. Criticism of the impact of stabilisation measures, therefore, by no means implies the unmitigated desirability of returning to an earlier policy regime.

However, specific targets for improvements in the human condition have not featured in any of the programmes (although this is now changing to some extent in Ghana). As a result, the particular forms taken by cuts in subsidies, in real wages and in real health and education expenditures under these progra mmes did have high social costs. In Zambia, for example, such costs explain much of the stop/go history of a decade of stabilisation efforts and certainly the 1986/87 collapse of the latest IMF/World Bank-supported reform programme. On the other hand, national reform programmes without international support would have found it almost impossible to take more account of human costs because they would have faced still lower state resources and import capacity. The Ghana programme of 1982 encountered this obstacle, and it seems likely that the nationally designed successor to the 
IMF/World Bank reform programme in Zambia will do likewise.

\section{Prices, Lags and Incentives}

The evidence certainly supports the contention that prices do matter. But the effects of price movements depend strongly upon country and product contexts. In Madagascar, for example, an initial rise in the price of rice deterred coffee production and it appears that devaluation raised the prices of non-tradeables relative to tradeables (or at least the price of distribution relative to produce prices).

Furthermore, country experiences do not suggest that a highly overvalued exchange rate can be fully protected (as with the disguised devaluation in Algeria) nor that it is anything but costly to try (Ghana, Zambia). But these experiences suggest - as does Charles Harvey's topical piece - that the process of adjusting away from non-marginal overvaluation is problematic. Two fairly free auctions - those in Sierra Leone and Zambia - generated an irreversible, free fall in the value of the domestic currency, and produced ridiculously low rates. Ghana's managed auction, on the other hand, has produced almost suspicious stability against the US dollar (itself devaluing) for over a year. These experiences, together with earlier single devaluations in Zambia and Madagascar which did not hold, suggest that a constrained system of market pricing (for example a 'crawling peg') for domestic currencies may be better than either fully administered or entirely marketdetermined regimes.

If any one message comes across squarely it is that lags are almost always under-estimated in stabilisation and adjustment programmes. Initial measures are typically adopted without adequate attention to identifying either optimal sequences or sequential interactions. The assumption of speedy response is integral to the IMF model - whose locus classicus appears to be near-industrial Mediterranean economies, e.g. Portugal, Turkey and - a decade ago - Italy. Three sub-assumptions appear to be: relatively nationally integrated and efficient markets; material conditions which allow a supply response to nominal incentives before subsequent price changes wipe them out; an ability to shift resources easily from producing for the home market to producing exports, thus raising output primarily by shifting resources from consumption to investment, from home to external markets and from non-tradeables to tradeables. Unfortunately, in none of the countries studied are any of the three sub-assumptions even approximately true - although arguably they are much closer to being so in Algeria than in the others.

Price changes in the context of physical constraints on output fail, or at best have very lagged results. Actions to reduce demand within inflexible production patterns reduce imports only by cutting real output and consumption, and may do next to nothing for exports. Highly imperfect markets may function even less well when some imperfections are removed without addressing others. 'Tradeables' proves, in practice, to be a very slippery term and non-tradeable sectors (especially those comprising the distribution of and speculation in tradeables) seem to have a marked ability to profit from change and uncertainty of any kind (including that introduced by faltering stabilisation programmes and rapidly declining auctiondetermined exchange rates).

In all the count ry cases (except Algeria) export raising was a major aim of stabilisation, but only in Ghana, and perhaps Malawi, does it seem to have had a significant positive impact. This paradox may relate in part to lags - some non traditional export growth from a very low base began to be seen in Zambia. But it is probably more strongly related to rigid production structures, poor prospects for traditional exports and resource constraints preventing underutilised manufacturing capacity being turned to export use.

In this context it is often argued that a medium term export rehabilitation strategy is needed. This, indeed, was included for cocoa in Ghana and, with less success, for copper/cobalt in Zambia. In addition, a long term non-traditional (diversification) export strategy is posited, based upon additional resource inputs as well as price incentives. If true, this means that a short term stabilisation programme is not a very suitable context for conceptualising export development nor, therefore, for achieving stability in the external balance. It also implies that significant net resource inflows to sustain stabilisation, adjustment and output recovery are likely to be necessary to bridge as much as a decade's lag before exports can grow enough to meet even minimum import requirements.

Non-price issues are hard to generalise - let alone conceptualise - and appear not to have been seriously considered in the design of most stabilisation programmes. Yet, it is almost conventional wisdom that price changes are at most necessary conditions which by themselves can rarely be sufficient. Our country case-studies do nothing to contravert that growing consensus.

With the exception of Algeria, the bottlenecks facing each country are similar - as are the ways in which they represent constraints on output growth. These include inadequate or debilitated transport systems, weak and discriminatory agricultural procurement (public and private), faulty industrial plant, and inadequate import capacity either to maintain the existing capital stock or to operate it at reasonable utilisation levels. These matters will not simply disappear as a result of changing relative prices - yet 
they are rarely given individual attention, still less material support. Taken together, however, they are capable of frustrating efforts to maintain a viable external balance - even if temporarily achieved as a result of measures to reduce domestic demand.

\section{Stabilisation with an Ahuman Face?}

There is no evidence that any country programme treated income distribution, access to basic services, minimum consumption needs, nutritional conditions, mortality and/or morbidity as issues to which an overall stabilisation programme should address itself. National or sectoral aggregates were the actors to be influenced and prices were the main policemen to exert that influence. Human beings - and their often desperate plight - were well nigh invisible in these programmes. Since people represent both the means toward and the justification for policy change, this is not a trivial gap.

Enabling the poor to produce more; using education and health to increase productivity; changing the economic structures which promote poverty and vulnerability - even these basically economic goals are hard to find (except partially in the cases of Algeria and Ghana).

The short-run effects have been harsh. Reductions in aggregate demand have hurt the poor. Employment has fallen - as has formal sector demand for informal sector goods and services. Basic services (health, education, water) have often been cut sharply. The impact has been greatest at the end of the line - rural areas with empty shops and silent clinics or schools; festering urban slums with next to no services; female headed households whose shaky means of support have been further undermined; the children of the poor who are now even less well nourished than they were before. Stabilisation as experienced in these cases has not had an inhuman face - if only because the poor seem to have been invisible to the designers. The face they have presented, therefore, has been characterised largely by an $a$ human lack of concern, or - at its most charitable - lack of forethought. An assumption is often made that taking only a macro perspective will not place the poor particularly at risk. That assumption, however, is false. Where incomes decline, the poor need particular protection precisely because many are already on the boundary of survival. In the countries studied there has not, in most cases, been a return to sustained growth. Thus, there have as yet been few medium or long term gains. Meanwhile, in the short run, the poor - and especially poor children - are only too frequently dead.

\section{Prices and the Poorest}

How prices affect the poorest depends on which prices and in what context. Urban wage earners and/or landless rural labour do not always comprise the majority of the poor. Such assumptions will generate misleading conclusions where - as in all seven country cases - they are false.

Higher food prices harm the urban poor and plantation workers - especially the poorest in the informal sector. But the characteristics of those who have had access to subsidised food are not clear rarely, in the present sample of countries, have the poorest had such access except perhaps in the urban areas of Zambia. However, the impact of removing subsidies should not be assumed to be small, as Sierra Leone's 1986/87 experience demonstrates. Although higher grower prices seem to be unambiguously desirable, they may not help if the primary cash income sources of the rural poor are not produce sales, as, for example, in Madagascar, or if parallel reforms tend to restrict the market access of such products, as happened with peripheral grain growers in Zambia.

Higher (or newly introduced) fees for basic services also hurt the poor unless they result in the provision of more public services and less dependence upon the private sector. It is worth noting that even poor urban Ghanaians have to pay private school fees. The reverse would be true of indirect tax boosted amenity prices (to reduce deficits and augment services) but these do not seem to have been central to any programme.

\section{Labour Market Rigidity: Myth or Constraint?}

Labour market constraints on effective adjustment is another area in which these country studies do not appear to confirm received conventional wisdom. In all of them, except perhaps Sierra Leone, real wages and salaries were reduced, and in some the reductions were very sharp. In none, however, does wage pressure per se seem to have been significant in the constellation of forces limiting success or leading to failure. Although it may seem pedantic to draw a strong distinction between low wages and high prices, its importance is given by the broader composition of interest groups involved in the latter case. Thus, it is interesting that even in Zambia the flashpoint was not, as exported, a miners' strike but riots which were sparked off by increases in the price of maize meal.

In fact the pattern that emerges - at least in some countries - is one of excessive reduction in real labour incomes which has impeded recovery by crippling consumer demand. Madagascar and Ghana in 1986 seem to illustrate this pattern. As 'excess' consumer goods could rarely be exported, the effect of reductions in the level of demand seem to have resulted in idle plant and subsequent declines in production with little, if any, offsetting gain in the health of the external balance. Equally, the absenteeism to which many public servants have been driven has - as in Zambia - reduced the quantity 
and quality of service provision. The same trend is probably driving down informal sector incomes still further as a result of increased worker participation in that declining market.

One problem for the interpretation of available data is that the income structures in poor households especially in West Africa - have altered radically. Even in the late 1970s one wage income from the formal sector could support a household. This is far from true today. Yet, as formal sector employment has stagnated or declined, multiple wage jobs cannot provide a general solution. Rather, households increasingly comprise several cash-earners, who are occupied in a range of formal and informal activities for various periods in the week. As yet there are few data available to assess the importance and generality of such trends.

\section{The Importance of Politics}

The country studies indicate that the politics of stabilisation matter enormously. The crucial bargaining usually concerns which groups are to lose and gain the most - if not directly, then in terms of future opportunity. Nevertheless the political character of the governments in the seven countries varies substantially, as do the politically dominant economic actors. Some of the extremes include the non-investing expatriate traders in Sierra Leone and the state planners and managers in Algeria. From this very diversity follow two implications: first, that generalisation across countries about the politics of stabilisation is at the least complex; second that the advocacy of a group of policies which are 'technically' determined - either on the (fallacious) grounds that they are neutral with respect to politics, or are simply 'required' to achieve stabilisation - is a naive approach. Those who seek the success of stabilisation measures need to incorporate explicit political analysis within the framework they use in order to derive locally appropriate policy reforms.

At the risk of offending their diversity, our studies suggest that states with low credibility for carrying through reformist measures will also have little success in making stabilisation credible. A dialogue about proposed policies within the decision-making group may (by achieving alterations when needed) strengthen the policies; open criticisms by established political leaders on the other hand, are likely to cripple or even kill them. The strength of the state relative to other economic actors (including its degree of control over public enterprises) seems to matter independently of its absolute strength. Support for the state is likely to be reduced by the initial costs of stabilisation. But whether the state seeks to counter this primarily by pushing for broader support (using dialogue, incentives, or parliamentary debate) as in Algeria and
Ghana, by increased authoritarianism, as in Malawi and Togo, or by a febrile alternation between the two, as in Sierra Leone and Zambia, seems to depend more upon the characteristics of the state than upon those of the stabilisation programme itself.

\section{Is there a Francophone Model?}

Despite having very different state ideologies (albeit both are military governments) and very different social patterns, Togo and Madagascar share several common characteristics as regards their economic structure and their stabilisation experiences. Both had a long history of poor growth performance until the 1970 s. Both tried a dash for growth through massive productive sector investment which was largely financed by external borrowing, but which did not pay off. With terms of trade collapsing, both countries had to adopt stabilisation measures. But both were nearly bankrupt, and with increases in concessional finance never offsetting falls in commercial credit, had much reduced import capacity. Both countries have also made high use of domestic arrears, i.e. unpaid contractors' instalments, purchase orders and - on occasion - payrolls. In Togo's case this was partly because, as a CFA zone member, it could neither devalue nor print money to cover government deficits. After over half a decade of stabilisation and fierce constraints on aggregate demand, however, neither country has achieved fiscal or external balance nor has there been any sign of a return to sustained growth. Apart from challenging the view that the francophone economies in general do better than anglophone - a view too much influenced by the experience of Ivory Coast prior to 1987 - this pattern does suggest some continuing colonial structures or procedural inheritance.

At first glance the Algerian experience could be taken to vindicate the new neo-liberal orthodoxy. In 1986 recurrent government spending was cut, as were imports and real wages. Prices rose sharply. Since 1980 the government increased agricultural incentives, excised a number of grandiose investment projects, and widened the scope for the private sector. While it has not devalued, Algeria has introduced de facto export retention, and it has abandoned foreign exchange licensing and conversion bonus schemes.

But this paradigm has only partial relevance. Algeria's strategic adjustment at the turn of the decade owed little to neo-liberal ideology - the commitment to a socialist, centrally planned economy fuelled by very high fixed capital formation remains strong. Agriculture, rural services, housing, and urban infrastructure were given new priority while education and health retained their importance. This was not therefore, a standard stabilisation package except for the place given to agriculture. Industrial strategy was 
rethought, both to increase the speed of project completion and utilisation and to be more selective. Industry however, remains central, and heavy industry is to stay either totally within the public sector or become run on a joint venture basis. Widening the scope for private enterprise and attempting reforms in the public sector - including reforms to the inconsistent price setting system - seem aimed more at a cost reduction and the stimulation of investment rather than indicating a commitment to privatisation per se. Lenin's new economic policy rather than that of Deng may thus be the more appropriate analogue.

\section{Influences on the Capacity to Stabilise}

'Adjustment fatigue' (Ghana) and 'stabilisation capacity' (Madagascar) are terms which highlight a more general theme appearing in most or all of the cases. The speed, sharpness, duration and short-term net benefits and costs all seem to influence the extent to which the policies are sustainable. Shock treatment appears to have worked in one case - Ghana - but in Zambia it has contributed to counter forces which have made stabilisation unsustainable. Here, it has actually prevented serious structural adjust ment. Oneoff non-marginal exchange rate shifts have (except for Ghana) tended to lag well behind over-valuation, to be eroded speedily and to raise more general conceptual problems for economic policy.

Nevertheless, some characteristics which do seem to influence the capacity of countries to stabilise and to sustain their new policy stance include:

- a self-evidently disastrous prior situation and trend, generating a consensus on the need for reform, if not on the need for what such changes should comprise;

- a reform programme based on a clear understanding of the domestic context and of its key variables;

- a consistent policy stance, in the context of which, reforms, once adopted, are not frequently or sharply reversed;

- firm support for national decision-makers, who have at least some capacity (by stick or carrot, loyalty or fear) to control the response of the most influential economic actors;

- propitious events - such as the ending of drought in Ghana in 1984, and the recovery, in 1987, of the oil price for Algeria;

- and, finally, enhanced import capacity bolstered by increased net foreign resource inflows.

These, for the country cases included in the present collection, have each had a singular effect in different national contexts.

\section{Books Received}

Rhys Jenkins, Transnational Corporations and Uneven Development: The Internationalization of Capital and the Third World, Methuen, London, 1987

Giovanni Andrea Cornia, Richard Jolly and Frances Stewart (eds), Adjustment with a Human Face: Vol I Protecting the Vulnerable and Promoting Growth. A Study by UNICEF, Clarendon Press, Oxford, 1987

Roger Plant, Sugar and Modern Slavery: A Tale of Two Countries, Zed Press, London, 1987

Jacobo Schatan, World Debt: Who is to Pay? Zed Press, London, 1987
Javier Gonzalo Alcalde, The Idea of Third World Development: Emerging Perspectives in the United States and Britain, 1900-1950, University Press of America/The White Burkett Miller Center of Public Affairs, Lanham (MD), 1987

Michael Ayre and Alan Smith, Puncture Prevention Techniques for Low Cost Vehicles, Intermediate Technology Publications, London, 1987

Gabriel Roth, The Private Provision of Public Services in Developing Countries, OUP/USA, 1987

Juan Carlos Puig, Integracion Latinoamerica $y$ Regimen Internacional/Latin American Integration and the International Regime, Universidad Simon Bolivar, Instituto de Altos Estudios de America Latina, Caracas, 1987 
Centro Interuniversitario de Desarrollo (CINDA)/Instituto de Altos Estudios de America Latina de la Universidad Simon Bolivar (IAEAL), Manual de Integracion Latinoamerica. Caracas, 1987

Kamran Mofid, Development Planning in Iran: From Monarchy 10 Islamic Republic, Middle East and North African Studies Press Ltd, Wisbech (Cambs), 1987

Michael Dover and Lee M. Talbot, To Feed The Earth: Agro-Ecology for Sustainable Development, World Resources Institute, Washington DC, 1987

The Tropical Agriculture Association (UK), Tropical Agriculturists: Future Prospects, British Council, London, 1987

Ibrahim S. R. Msabaha and Timothy M. Shaw (eds.), Confrontation and Liberation in Southern Africa. Gower, Aldershot, 1987

United Nations Centre for Human Settlements (HABITAT), Global Report on Human Settlements 1986. OUP, 1987

John Cleland and Chris Scott, The World Fertility Survey: An Assessment, Clarendon Press, Oxford, 1987

Standards and Specifications for Local Building Materials, Report of the ARSO/CSC/UNCHS Workshop, Nairobi, 16-24 March 1987, Intermediate Technology Publications, London, 1987

J. L. Enos and W. H. Park, The Adoption and Diffusion of Imported Technology: The Case of Korea. Croom Helm, Beckenham, 1987

David D. Laitin and Said S. Samatar, Somalia: Nation in Search of a State. Gower, Aldershot, 1987

Sarah Lancashire, Jeff Kenna and Peter Fraenkel, Windpumping Handbook, Intermediate Technology Publications, London, 1987

Alasdair I. MacBean and D. T. Nhuyen, Commodity Policies: Problems and Prospects, Croom Helm, Beckenham, 1987

Derek Hayward and Julius Oguntoyinbo, Climatology of West Africa. Hutchinson Education, London, 1987

James Riedel, Myths and Reality of External Constraints on Development, Gower/Trade Policy Research Centre, London, 1987
John W. Warnock, The Politics of Hunger, Methuen, Toronto, 1987

Douglas Horton, Potatoes: Production, Marketing, and Programmes for Developing Countries, Westview Press (Boulder) IT Publications (London), 1987

J. Clyde Mitchell, Cities, Society and Social Perception. A Central African Perspective, Clarendon Press, Oxford

D. Gale Johnson and Ronald D. Lee (eds.), Population Growth and Economic Development: Issues and Evidence, University of Wisconsin Press, Madison, 1987

R. H. Young and C. W. MacCormac (eds.), Market Research for Food Products and Processes in Developing Countries: Proceedings of a Workshop held in Singapore, 1-4 April 1986. IDRC, Ottawa, 1987

J. Hinderink and J. J. Sterkenburg, Agricultural Commercialization and Government Policy in Africa. KPI, London, 1987

Vincent Cable and Bishnodat Persaud (eds.), Developing with Foreign Investment, Croom Helm, Beckenham, 1987

Consumers Association, Plastic Below'-Ground Components, London, 1987

Centre for Socio-Legal Studies, Annual Report 1985-86, Oxford, 1987

Christopher J. Harris et al., Investment and Shadow Pricing in a Growing Economy With Tax Restrictions, Discussion Paper 87-21, Dept of Economics, University College, London, 1987

George Catephores, Good Policy, Bad Economics: Ezra Pound's Economic Poetry', Discussion Paper 87-19, Dept of Economics, University College, London, 1987

P. N. Mathur, Price Behaviour with Vintage Capital, Discussion Paper 87-20, Dept of Economics, University College, London, 1987

Peter Skott, Finance Accumulation and Choice of Technique. Discussion Paper 87-07, Dept of Economics, University College, London, 1987

Cento Veljanovski, Commercial Broadcasting in the UK Over-regulation and Mis-regulation? Discussion Paper 87-77, Dept of Economics, University College, London, 1987 